\title{
The effect of chronic respiratory diseases in calves on the serum protein electrophoretic pattern
}

\author{
Csilla Tóthová1, Oskar Nagy ${ }^{1}$, Herbert Seidel $^{2}$, Gabriel Kováč $^{1}$ \\ ${ }^{1}$ University of Veterinary Medicine and Pharmacy, Clinic for Ruminants, ${ }^{2}$ Clinic for Swine, Košice, \\ Slovak Republic \\ Received March 20, 2012 \\ Accepted September 19, 2012
}

\begin{abstract}
The aim of this study was to evaluate the effect of chronic respiratory diseases in calves on the serum protein electrophoretic pattern. Twenty five calves of the Slovak Spotted breed, Lowland Black Spotted breed, and their crossbreeds with clinical symptoms of chronic respiratory diseases were included into this study. Blood serum was analyzed for the total serum protein concentrations, and the relative and absolute values of serum protein fractions. The results obtained in sick animals were compared with those in 29 clinically healthy calves of the same age and breed. In the calves suffering from chronic respiratory diseases, we found significantly $(P<0.001)$ higher total serum protein concentrations than in healthy calves. In sick calves a marked shift in the concentrations of the most of protein fractions was observed, with significantly higher values of $\alpha_{1}-, \beta_{1}-, \beta_{2}-$ and $\gamma$-globulins $(P<0.001, P<0.05, P<0.001$, and $P<0.01$, respectively). On the other hand, the concentrations of albumin in the calves with respiratory diseases were significantly $(P<0.001)$ lower than those measured in healthy ones. The presented results indicate a marked effect of chronic respiratory diseases in calves on the serum protein electrophoretic pattern, with a shift in the albumin and globulin concentrations, which could be useful for clinicians for better evaluation of the pathological changes in affected animals.
\end{abstract}

Cattle, bronchopneumonia, electrophoresis, serum protein fractions

Together with diarrhoea, respiratory tract diseases constitute the main health problem and overall the most common cause of morbidity and mortality in calves and young cattle (Svensson et al. 2006). In case of dairy calf pneumonia, diagnosis and treatment are mainly based on the observation of clinical symptoms. However, in many cases, the infected calves show only mild clinical symptoms that could be easily missed in a group of calves on a farm (Gänheim et al. 2003). Therefore, there is a need for objective indicators of health or disease in calf herds applicable to laboratory diagnosis of diseases. Several blood indicators (e.g. total leukocyte count) have been introduced to indicate inflammatory diseases including respiratory diseases (Fulton et al. 2002). However, the use of total leukocyte count to detect infection is not informative enough in cattle like in many other species (Kidd 1991). Objective indicators of animal health such as the measurement of serum protein fractions could be useful for identifying diseased animals.

Serum protein electrophoresis is a laboratory technique used to separate serum proteins by size and electrical charge, thus allowing the identification and quantification of protein fractions (Cerón et al. 2011). Although it provides useful information on the pathological conditions associated with disorders of the protein profile, serum protein electrophoresis in cattle is a rarely used laboratory method. Indications for serum protein electrophoresis in humans include hyperproteinaemia and suspicion of plasma cell neoplasia as well as investigation of hepatic diseases (Vavricka et al. 2009). In veterinary medicine, previous reports described the serum protein electrophoretic pattern in small animals, goats, and horses, predominantly in hepatic, endocrine, and infectious diseases (Sevelius and Andersson 1995; Janků et al. 2011). However, identification of serum protein fractions

Address for correspondence:

Csilla Tóthová, DVM, PhD.

Clinic for Ruminants, University of Veterinary Medicine and Pharmacy

Komenského 73, 04181 Košice, Slovak Republic
Phone: +421915493082
Fax: +4215567 11674
E-mail: tothova@uvm.sk
http://actavet.vfu.cz/ 
in cattle with various organ diseases is not so well documented, predominantly in chronic cases.

Therefore, the aim of this study was to determine whether chronic respiratory diseases in calves cause changes in the serum protein electrophoretic pattern.

\section{Materials and Methods}

Animals and clinical examination

Twenty-five calves with clinical signs of chronic respiratory diseases of varying intensity were included into this study. The calves were of the Slovak Spotted breed, Low-land Black Spotted breed, or their crossbreeds. The age of the calves ranged from 4 to 6 months, and their body weight from 85 to $140 \mathrm{~kg}$. The animals were taken to the Clinic for Ruminants of the University of Veterinary Medicine and Pharmacy in Kosice by private veterinarians from three different conventional dairy farms. The same feeding and management regimes were applied to calves from these herds. At the clinic, the calves were housed individually, fed twice a day with free access to water.

After the arrival to the clinic, all calves were thoroughly examined using standard clinical examination procedures focused on the general health state (body temperature, food intake, behaviour), and then especially on the respiratory system (Jackson and Cockcroft 2002). The respiratory system was examined by visual inspection (breathing rate, nasal discharges, dyspnoea and cough) and auscultation (increased or decreased loudness of the breathing sounds, bronchial sounds, abnormal breath sounds). This study included calves manifesting clinical signs of the disease for more than 2 weeks despite the antimicrobial, antiinflammatory, and supportive therapy done by private veterinarians on the farm. The chronicity of the disease was defined from the pacient history. The animals did not show any pathological lesions on the other organ systems. To compare the evaluated variables between sick and healthy animals, 29 clinically healthy calves from a conventional dairy farm were used as a control group. These calves were of the same age and breed like the calves with respiratory diseases. They were in good general health without any obvious signs of disease.

Sample collection

Blood samples were taken from both healthy and sick animals once after initial clinical examination. Blood samples were collected by a direct puncture of $\mathrm{v}$. jugularis into serum gel separator tubes without anticoagulant. The separated serum was stored at $-20{ }^{\circ} \mathrm{C}$ until analyzed for the total serum protein concentrations, and identification of serum protein fractions.

Laboratory analyses

Total protein (TP, g/l) concentrations in blood serum were assayed in the automated biochemical analyzer Alizé (Lisabio, France) by the biuret method using commercial diagnostic kits (Randox, United Kingdom). Serum protein fractions were separated by zone electrophoresis on the buffered agarose gel at $\mathrm{pH} 8.8$ on an automated electrophoresis system Hydrasys (Sebia Corporate, France) using commercial diagnostic kits Hydragel 7 Proteine (Sebia Corporate) according to the procedure described by the manufacturer. The electrophoretic migration was performed for $15 \mathrm{~min}$ at $20^{\circ} \mathrm{C}$ constantly at $10 \mathrm{~W}, 40 \mathrm{~mA}$, and $240 \mathrm{~V}$. After migration, the gels were stained in amidoblack staining solution, and then destained by acidic solutions and dried completely. The electrophoretic gels were scanned, and the serum protein fractions were visualized and displayed on the densitometry system Epson Perfection V700 (Epson America Inc., California, USA) by light transmission and automatic convertion into an optical density curve presentation. Protein fractions were identified and quantified by computer software Phoresis version 5.50 (Sebia Corporate). Serum proteins were separated into the following fractions in the order from the fastest to the slowest mobilities: albumin, alpha ${ }_{1}\left(\alpha_{1}\right)-$, alpha ${ }_{2}\left(\alpha_{2}\right)-$, beta $_{1}\left(\beta_{1}\right)-$, beta $\left(\beta_{2}\right)-$, and gamma $(\gamma)-$ globulins. The relative concentrations (\%) of protein fractions were determined as the percentage of the optical absorbance, and the absolute concentrations $(\mathrm{g} / \mathrm{l})$ were calculated from the total serum protein concentrations. Albumin: globulin ratios $(\mathrm{A} / \mathrm{G})$ were computed from the electrophoretic scan.

\section{Statistical analyses}

Arithmetic means (x) and standard deviations (SD) for the evaluated variables were calculated using the descriptive statistical procedures. Mann-Whitney non-parametric test was used to compare the results and to evaluate the significance of differences in the values measured between healthy and sick calves. All statistical analyses were performed using the computer programme GraphPad Prism V5.02 (GraphPad Software Inc., California, USA).

\section{Results}

The data referring to the total protein concentrations, and the relative and absolute values of protein fractions in healthy calves and the calves with respiratory diseases, including the significance of differences in the values measured between the groups of animals, are listed in Table 1. The analysis of individual values of total serum proteins, albumin, and A/G ratio 
Table 1. Concentrations of total serum proteins, serum protein fractions, and $\mathrm{A} / \mathrm{G}$ ratios in clinically healthy calves and calves suffering from chronic respiratory diseases $(x \pm \mathrm{SD})$.

\begin{tabular}{lccc}
\hline Indicator & \multicolumn{3}{c}{ Group of calves } \\
\hline \multirow{3}{*}{ Total protein } & $\mathrm{g} / \mathrm{l}$ & $70.3 \pm 4.89$ & $78.4 \pm 11.21^{* * *}$ \\
Albumin & $\mathrm{g} / \mathrm{l}$ & $33.4 \pm 3.07$ & $28.2 \pm 5.15^{* * *}$ \\
& $\%$ & $47.7 \pm 4.37$ & $36.7 \pm 8.39 * * *$ \\
$\alpha_{1}$-globulins & $\mathrm{g} / \mathrm{l}$ & $9.8 \pm 1.59$ & $12.2 \pm 2.10^{* * *}$ \\
& $\%$ & $13.9 \pm 1.91$ & $15.7 \pm 2.92^{*}$ \\
$\alpha_{2}$-globulins & $\mathrm{g} / \mathrm{l}$ & $3.2 \pm 0.67$ & $3.2 \pm 0.79$ \\
& $\%$ & $4.5 \pm 0.97$ & $4.2 \pm 1.36$ \\
$\beta_{1}$-globulins & $\mathrm{g} / \mathrm{l}$ & $6.4 \pm 0.71$ & $7.6 \pm 2.16^{*}$ \\
& $\%$ & $9.1 \pm 1.16$ & $9.6 \pm 2.18$ \\
$\beta_{2}$-globulins & $\mathrm{g} / \mathrm{l}$ & $5.4 \pm 1.43$ & $7.8 \pm 3.33 * * *$ \\
& $\%$ & $7.7 \pm 1.83$ & $9.8 \pm 3.28^{* *}$ \\
$\gamma$-globulins & $\mathrm{g} / \mathrm{l}$ & $12.2 \pm 3.34$ & $19.5 \pm 8.04 * *$ \\
& $\%$ & $17.1 \pm 3.90$ & $24.0 \pm 7.72^{* * *}$ \\
A/G & & $0.92 \pm 0.15$ & $0.61 \pm 0.22^{* * *}$ \\
\hline
\end{tabular}

*asterisks in rows mean significant differences between healthy and diseased animals: $* P<0.05, * * P<0.01, * * * P$ $<0.001$ other hand, the concentrations of $\alpha_{2}$-globulins did not differ significantly between the two groups of animals (Table 1). Significant effects of chronic respiratory diseases were detected also in the $\beta_{1}$ - and $\beta_{2}$-globulin fractions. The absolute concentrations found in sick calves were significantly higher than the results recorded in clinically healthy animals $(P<0.05$ and $P<0.001$, respectively). Similarly, the absolute and relative concentrations of $\gamma$-globulins differed significantly between the evaluated groups of calves with higher values in the animals with respiratory signs

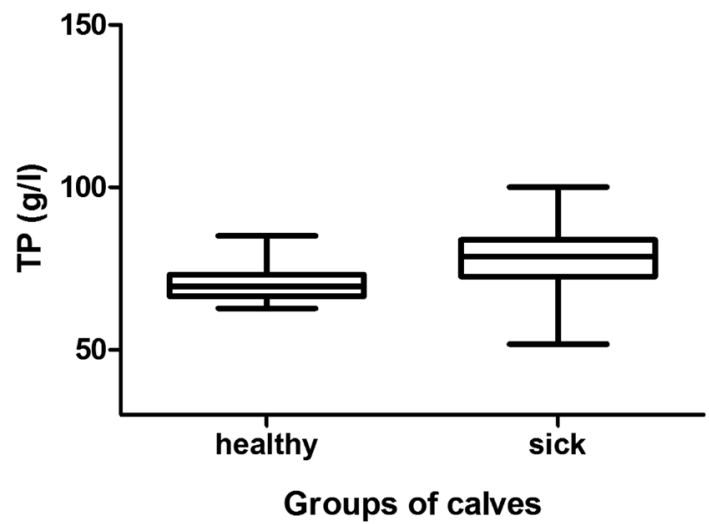

Fig. 1. Distribution of total serum protein concentrations in clinically healthy calves and calves suffering from chronic respiratory diseases. The plots show the median (line within box), $25^{\text {th }}$ and $75^{\text {th }}$ percentiles (box), minimal and maximal values (whiskers). 


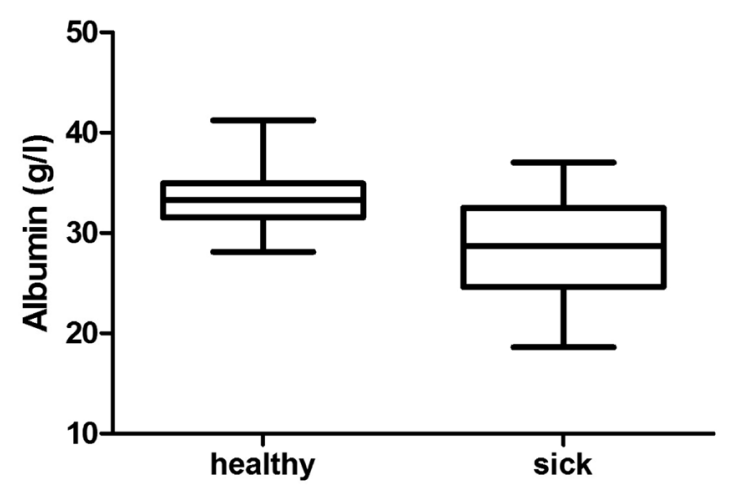

Groups of calves

Fig. 2. Distribution of albumin concentrations in clinically healthy calves and calves suffering from chronic respiratory diseases. The plots show the median (line within box), $25^{\text {th }}$ and $75^{\text {th }}$ percentiles (box), minimal and maximal values (whiskers).

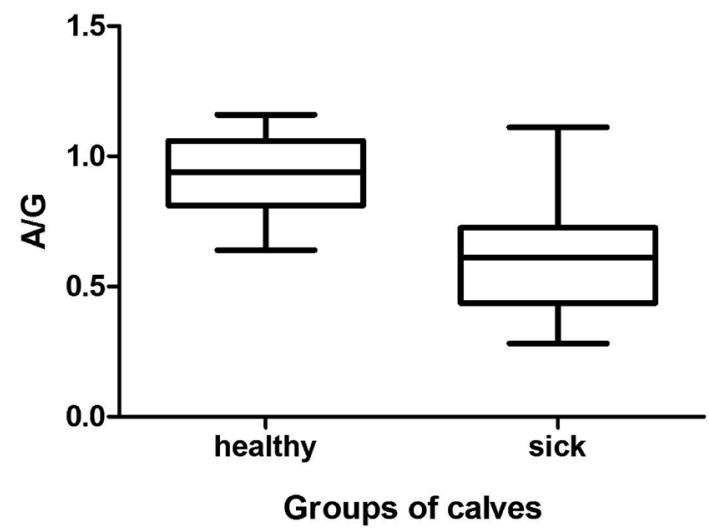

Fig. 3. Distribution of $\mathrm{A} / \mathrm{G}$ values in clinically healthy calves and calves suffering from chronic respiratory diseases. The plots show the median (line within box), $25^{\text {th }}$ and $75^{\text {th }}$ percentiles (box), minimal and maximal values (whiskers).

( $P<0.001$ and $P<0.001$, respectively). The $\mathrm{A} / \mathrm{G}$ ratio in the calves with chronic respiratory diseases was significantly lower $(P<0.001$, Fig. 3$)$.

\section{Discussion}

In humans, serum protein electrophoresis is a common technique of laboratory diagnosis used to identify patients with multiple myeloma and to investigate serum dysproteinaemias (O'Connell et al. 2005). In small animal and equine medicine, indications for performing the serum protein electrophoresis have largely centred on the screening for gammopathies and immunodeficiences (Mair et al. 1993; Tappin et al. 2011). On the other hand, there are only scarce data regarding the serum protein electrophoretic pattern in cattle with various diseases, and the studies were performed some years ago. Some data were presented earlier in cows suffering from traumatic reticuloperitonitis, with a decrease of 
the albumin and increase of globulin concentrations (Yoshida 1986). However, scarce information has been published regarding the changes in albumin and globulin fractions in cattle with respiratory diseases.

Results in this study showed a significant effect of respiratory diseases in calves on the concentrations of the most of serum protein fractions. The relevance of protein fractions for the detection of calves with bronchopneumonia was investigated earlier only by Humblet et al. (2004), who suggested significant differences between diseased and recovered calves for total serum proteins, albumin, $\beta_{1}$ - and $\gamma$-globulins. All these serum proteins increased from the diseased to the recovered status, except $\gamma$-globulins, which decreased. In our study, comparison of serum protein fractions between healthy and sick animals showed significantly higher concentrations of $\alpha_{1}$-globulins in the calves with respiratory tract diseases. According to Carapeto et al. (2006), acute inflammatory diseases usually lead to an increase of the $\alpha_{1}$-globulin fraction, which may be associated with higher concentrations of some acute phase proteins (haptoglobin, ceruloplasmin, $\alpha_{1}$-acid glycoprotein) from this fraction. However, seeing that the globulin fractions include a number of proteins, additional studies using high resolution electrophoresis are needed to identify the individual proteins associated with increased $\alpha_{1}$-globulins in the calves suffering from respiratory diseases.

Cerón et al. (2011) noted that increased $\alpha$-globulin concentrations are indicative of acute inflammation. Our results suggest that not only acute inflammatory diseases, but also chronic infections may be associated with higher concentrations of $\alpha_{1}$-globulins. Tymchak (2010) reported that chronic infections may produce an increase in globulin fractions, predominantly in $\gamma$-globulins, but also in the $\alpha$ - and $\beta$-globulin fractions, which is accompanied by a decrease of albumin. These data are in agreement with our findings, as in the calves suffering from chronic respiratory diseases we found significantly higher concentrations of $\beta$-, as well as $\gamma$-globulins, but significantly lower values of albumin. Seeing that the gamma region is composed predominantly of antibodies of the IgG type, higher concentrations of $\gamma$-globulins obtained in the calves with chronic respiratory diseases may reflect the response of the organism to inflammation (Taylor et al. 2010). Stockholm and Scott (2008) stated that decreased albumin and increased globulin concentrations are the most common pattern in animals with inflammatory diseases, reflecting the compensatory reduction in albumin concentrations to maintain oncotic pressure and viscosity. This shift in albumin and globulin concentrations resulted in significantly lower $\mathrm{A} / \mathrm{G}$ ratio in calves affected by chronic respiratory diseases.

In conclusion, the present study suggests that chronic respiratory diseases in calves may affect the serum protein electrophoretic pattern with a marked shift in the albumin and globulin concentrations. While the concentrations of $\alpha_{1^{-}}, \beta_{1}-, \beta_{2}^{-}$, and $\gamma$-globulins were significantly higher in the calves with respiratory diseases, the albumin values were significantly lower in the affected calves. Seeing that the changes in the serum protein electrophoretic pattern in the calves with chronic respiratory diseases are not sufficiently evaluated, the obtained data could be useful for clinicians for the determination of health status and evaluation of the pathological changes in the affected animals. However, further studies would be helpful to clarify the effect of these diseases on the concentrations of globulin fractions and their changes during the disease process, as these findings are clinically important for identifying the inflammatory process as active, which may be helpful in achieving a final diagnosis.

\section{Acknowledgements}

This work was supported by the Slovak Research and Development Agency under the contract No. APVV0475-10 and by VEGA Scientific Grants No. 1/0592/12 and 1/0812/12 from the Ministry of Education. 


\section{References}

Carapeto MV, Barrera R, Maňe MC, Zaragoza C 2006: Serum $\alpha$-globulin fraction in horses is related to changes in the acute phase proteins. J Equine Vet Sci 26: 120-127

Cerón JJ, Caldin M, Martinez-Subiela S 2011: Answers to some common questions on serum protein electrophoresis. Vet Rec, doi: 10.1136/vr.d2689

Fulton RW, Cook BJ, Step DL, Confer AW, Saliki JT, Payton ME, Welsh RD, Blood KS 2002: Evaluation of health status of calves and the impact of feedlot performance: assessment of a retained ownership program for postweaning calves. Can J Vet Res 66: 173-180

Gänheim C, Hultén C, Carlsson U, Kindahl H, Niskanen R, Persson Waller K 2003: The acute phase response in calves experimentally infected with bovine viral dirrhoea virus and/or Mannheimia haemolytica. Vet Med Brno 50: 1-8

Humblet M-F, Coghe J, Lekeux P, Godeau JM 2004: Acute phase protein assessment for an early selection of treatments in growing calves suffering from bronchopneumonia under field conditions. Res Vet Sci 77: 41-47

Jackson PGG, Cockcroft PD 2002: Clinical examination of farm animals. Blackwell Science Ltd., Blackwell Publishing Company, Oxford, United Kingdom, pp. 1-112

Janků L, Pavlata L, Misurova L, Filípek J, Pechova A, Dvorak R 2011: Levels of protein fractions in blood serum of periparturient goats. Acta Vet Brno 80: 185-190

Kidd R 1991: Interpreting neutrophil numbers. Vet Med 86: 975-982

Mair TS, Cripps PJ, Ricketts SW 1993: Diagnostic and prognostic value of serum protein electrophoresis in horses with chronic diarrhoea. Equine Vet J 25: 324-326

O'Connell TX, Horita TJ, Kasravi B 2005: Understanding and interpreting serum protein electrophoresis. Am Fam Physician 71: 105-112

Sevelius E, Andersson M 1995: Serum protein electrophoresis as a prognostic marker of chronic liver disease in dogs. Vet Rec 137: 663-667

Stockholm SL, Scott MA 2008: Proteins. In: Stockholm SL, Scott MA (Eds.): Fundamentals of veterinary clinical pathology. 2nd ed., Blackwell, pp. 369-413

Svensson C, Hultgren J, Oltenacu PA 2006: Morbidity in Swedish dairy calves from 3 to 7 months of age and risk factors for diarrhoea and respiratory disease. Prev Vet Med 74: 162-179

Tappin SW, Taylor SS, Tasker S, Dodkin SJ, Papasouliotis K, Murphy KF 2011: Serum protein electrophoresis in 147 dogs. Vet Rec 168: 456-462

Taylor SS, Tappin SW, Dodkin SJ, Papasouliotis K, Casamian-Sorrosal D, Taker S 2010: Serum protein electrophoresis in 155 cats. J Feline Med Surg 12: 643-653

Tymchak LL 2010: Amino acids and proteins. In: Bishop ML, Fody EP, Schoeff LE (Eds.): Clinical chemistry: techniques, principles, correlations. Lippincott Williams \& Wilkins, Philadelphia, USA, pp. 223-265

Yoshida Y 1986: Levels of serum protein, protein fractions and minerals in dairy cow with traumatic gastritis of various conditions. Jpn J Vet Sci 48: 1153-1159

Vavricka SR, Burri E, Beglinger C, Degen L, Manz M 2009: Serum protein electrophoresis: an underused but very useful test. Digestion 79: 203-210 